\title{
Rebranding Strategy Center Of Pottery As Tourism Iconic: Case In Indonesia
}

\author{
Hartono $^{1}$, Resista Vikaliana ${ }^{2}$ and Erni Prasetiyani ${ }^{3}$ \\ \{resista@stiami.ac.id $\left.{ }^{2}\right\}$ \\ ${ }^{1,2}$ Faculty of Administration, Institut Ilmu Sosial dan Manajemen STIAMI, Indonesia \\ ${ }^{3}$ Faculty of Social Science and Management, Institut Ilmu Sosial dan Manajemen STIAMI, Indonesia
}

\begin{abstract}
The purpose of this research is to identify internal and external factors in developing the rebranding of the Pottery Center in Indonesia strategy to become an iconic tourism. This study took the case in Purwakarta and Yogyakarta, which are two of the largest number of pottery centers in Indonesia. The approach of this research is a mixed method, which is an approach to quantitative and qualitative research, with a descriptive research type. Data collection with a qualitative approach is carried out through in-depth interviews with business actors in the pottery center, buyers and surrounding communities. In addition, also carried out observation and study of documents. In a quantitative approach, a questionnaire is used as a data collection technique. Quantitative and qualitative approaches are carried out simultaneously. Based on research results are identified internal stable quality of raw materials and unique products and different inventory management flaws, while external factors are optimizing government support, especially local government and providing additional working capital through credit for business development. It can be concluded the formulation of the rebranding strategy of the Pottery Center in Indonesia is by market penetration, market development, and product development.
\end{abstract}

Keywords: Rebranding Strategy, Tourism Iconic, Indonesian Pottery Center, Mixed Method Analysis

\section{Introduction}

In Indonesia the term 'pottery' is also known as traditional ceramics as a result of rural community crafting activities from clay, occupied for generations. Pottery is also called folk ceramics, because it has the characteristics of using low burnt clay and simple burning techniques. Almost every island in Indonesia, there are pottery making including: Mayong (Jepara), Klampok (Purwokerto), Jatiwangi, (Majalengka), Dinoyo (Malang), Lombok (West Nusa Tenggara), and Takalar (South Sulawesi), Plered (Purwakarta ), Sitiwangun (Cirebon), Kasongan (Yogyakarta), Banjarnegara (Bandung), Kapal (Bali).

This study focuses on Indonesian Pottery Production Centers in Plered and Kasongan. Both places were chosen because they have been going on for a long time and cover a large area. Activities in making clay crafts in both places have been passed down through generations. Plered Pottery Center is located in the southern region of Purwakarta Regency with traditional pottery production and decorative function ceramics located in Anjun Village. While the Kasongan Pottery Center is in Kasongan Village, Yogyakarta. Most of the population actually earn a living as ceramic craftsmen and have produced various kinds of souvenirs. There are two types of pottery that are produced in Kasongan, namely souvenirs, from the decoration of mini sculptures to piggy banks, and home furnishings for interior and exterior. 
The development of the business world today requires companies that are involved in it to be able to face competition that is increasingly tight. Various efforts and strategies must continue to be carried out in order to maintain the survival of the company. Tight competition along with the increasing maturity level of a product sometimes makes companies need to rebrand. Rebranding itself is an effort made by the company in changing the total or renewing the company's brand to be even better. Rebranding itself is not a new thing in the business environment. Rebranding can be done by companies or businesses engaged in any field, including one of the pottery centers in Indonesia, to remain in business competition.

The previous study from (Ločmele and Mousten, 2016) shows how Riga and Arhus identified, formulated and communicated city re-branding. Our analysis concentrates on resident responses to city re-branding and how such responses could force the municipalities to withdraw their re-branding. A city loses its identity if it is globalized. In the Riga and Aarhus cases, the municipalities tried to find a global voice, which contradicted local traditions; and in both cases, the redefinition of city image took place top-down and not bottom-up. The two cases may not prove to be a golden rule, but should be a warning against rash city re-branding decisions made by municipalities.

(Samuel, 2015) analyze that urban railway infrastructures as landscapes in order to reveal their role as con-structions and constructors of collective and individual identities in his article. The article argues that the rebranding strategy pursued by one of the city's municipal transport authorities provides one of the earliest examples of an attempt to manufacture a unified identity for the New Berlin. The article highlights that while processes at the municipal level emphasised the unification of collective identities, experiences of the infrastructures themselves often involved persisting divides and forms of subversion and social conflict that highlighted the meeting of more diverse individual identities.

Rebranding research is generally done on companies. But the two previous studies were carried out on public facilities. The study shows that a rebranding strategy is also required on public facilities to identify the identity of public facilities. In this study, the pottery center, both Plered Purwakarta and Kasongan Yogyakarta were public facilities that also functioned to conduct trade transactions. By carrying out a rebranding strategy, it is hoped that the Pottery Center in Indonesia can become a global tourism icon.

Based on the previous exposure, the aim of this study was to identify internal and external factors in developing the rebranding strategy of the Pottery Center in Indonesia to become a tourism icon (case studies in Purwakarta and Yogyakarta).

\section{Literature Review}

\subsection{Strategy}

Strategies in a special sense are actions that are continuous, experience improvement and are carried out according to the point of view about what is desired and expected by consumers in the future (Sedarmayanti, 2014). Based on this understanding, it can be concluded that in the business environment, the strategy must be dynamic, where the application will always adjust to changes in the desires and expectations of consumers. 


\subsection{Brand}

Keller (in (Tjiptono, 2005)) defines brands as products that can provide additional dimensions that uniquely distinguish them from other products designed to satisfy similar needs. These differences can be rational and tangible (related to the performance of the product of the relevant brand) or symbolic, emotional and intangible (with respect to brand representation). It can be concluded that technically when a company makes names and logos, the company has created a brand. But not only that, the brand is not just a symbol but also an element that is able to distinguish a product from other products.

\subsection{Rebranding}

(Prayudi; Juanita, 2005) define rebranding as an effort made by a company or institution to totally change or renew an existing brand in order to be better, by not ignoring the original purpose of the company. In the rebranding process, there are four important elements in it, namely repositioning, renaming, redesigning and relaunching (Muzellec, 2003). Rebranding is an effort or effort made by an institution to totally change or renew an existing brand in order to be better, by not ignoring the company's initial goal of profit-oriented. According to (Lambkin and Muzellec, 2010) the definition of rebranding is to create a new name, term, symbol, design, or a combination all for one brand, which cannot be denied with the aim of developing new differentiation or positions in the minds of stakeholders and competitors.

The purpose of rebranding is to change the company's image, to refine the company's brand, to improve the brand image, to be more widely known, to change the company's segments and targets, as well as various other corporate objectives in the rebranding process against the public. Therefore, rebranding activities will not provide maximum benefits, if not properly communicated to the public.

There are four important elements that form a rebranding process. These elements are repositioning, renaming, redesigning and relaunching (Muzellec, 2003). Repositioning is a decision taken by a company to form a new position for the company in the minds of consumers, competitors, and owners of interests (Ries and Trout, 2001, as quoted from (Muzellec, 2003).

Re-naming of companies is sometimes done to send signals to stakeholders that the company is making changes, both from the strategy and ownership of the company. At this stage changes also occur in the company slogan. (Lambkin and Muzellec, 2010). Redesign is carried out on all elements that appear in the company, for example stationery, brochures, iklam, annual reports, offices, and other elements that can be seen (Muzellec, 2003). Relaunch is the last stage, where at this stage an attempt is made to communicate changes made to the public in order to form awareness (Muzellec, 2003). The purpose of this process is to make the audience of the Pottery Center in Indonesia aware of the new brand offered by the Pottery Center in Indonesia. The things done by the Pottery Center in Indonesia in communicating rebranding carried out to outside audiences, among others, by conducting endorsements, placing banners, cooperating with third parties, and holding interesting events. 


\section{Method, Data and Analysis}

Research is essentially an attempt to find the truth or to justify the truth. The effort to get the truth done by using paradigm. The research paradigm is a set of concepts, beliefs, assumptions, values, methods, or rules that form the framework for carrying out a study. The paradigm used in this research is the paradigm of social constructivism. Social constructivism reinforces the assumption that individuals are always trying to understand the world in which they live and work. They develop subjective meanings of their experiences, meanings directed at certain objects or objects (Creswell, 2014).

The research approach used in this research is mixed method, that is using quantitative and qualitative research approach. The quantitative approach is done using IFE Matrix, EFE Matrix, SWOT Analysis and IE Matrix and QSPM Matrix.

Qualitative research is a method to explore and understand the meaning that comes from social or humanitarian problems (Creswell, 2014). In this study, a qualitative approach is done by analyzing the important elements in the rebranding process. There are four important elements that form a rebranding process. These elements are repositioning, renaming, redesigning and relaunching (Muzellec, 2003). The data obtained in the qualitative approach is then processed using a qualitative data analysis model. Qualitative data analysis technique used in this research is Model Miles and Huberman.

\section{Result and Discussion}

The research approach taken is the mixed method, which is a quantitative and qualitative research approach, with a descriptive type of research. Based on quantitative analysis, internal factors identified that the main strength of the Pottery Center in Indonesia was the good and stable quality of pottery as well as new employment factors from the handicraft industry, both with a score of 0.410 . The lowest score that illustrates the main weaknesses of the Pottery Center in Indonesia, there are 4 factors, namely: The Pottery Center in Indonesia has not used the information and communication technology to the maximum, there is no handicraft inventory management, the ability to innovate handicraft products, and the craft packaging skills, with score of 0.051. Overall, internal factors are at a score of 3.179.

While external factors identify the main opportunities are revolving funds from local governments, government support through development programs and support from local government officials with a score of 0.5 . The lowest score describing the main threat of the Pottery Center in Indonesia is the factor of applying minimal handicraft packaging technology, government policies (eg local taxes and retribution), the existence of competing products, the dependence of the production process on the climate (drying and others) with a score of 0.125 . Overall, external factors that are strongly supported to maintain their position are 3.188.

Based on Internal-External (IE) Matrix, the results show the formulation of the rebranding strategy of the Pottery Center in Indonesia to be an icon from Purwakarta formulated in the cell for II. According to (David, 2011), Grow and Build Strategy becomes the main strategy in cell II. The suitable strategy for cell II is an intensive strategy (market penetration, market development, and product development) or integrative (backward integration, forward integration, and horizontal integration).

The results of the qualitative analysis were carried out with the Miles Huberman Model data analysis technique. Qualitative analysis is based on secondary data, 
observations and interviews with 5 informants, consisting of 2 wholesalers and 3 buyers at the Pottery Center in Indonesia. While at Kasongan Pottery Center Yogyakarta, informants consist of 2 big traders, cooperative management, and 2 buyers. Based on a qualitative analysis, several things related to the strength factor of the Pottery Center in Indonesia to carry out a rebranding strategy are the quality of stable raw materials, having unique and different products and having a clear market segment. The existence of HIMKI (Indonesian Craft Association) strengthens efforts at the Center of Earthenware in Indonesia in a formal institution. While the known weaknesses of the in-depth interview are poor inventory and storage management. Warehouse is managed conventionally, and inventory is not recorded systematically. Inventory that is always in the warehouse is a variety of models that become regular customer orders (customers from Jakarta, Bandung, Bogor and others). The production process is carried out according to the standard of making pottery, and if it turns out that the production capacity has been optimum, then it will be 'mapped' (transfer of production) to other producers.

From external factors it is found that there is support to the industry, although not enough to help much on post-production performance activities. The local government has provided a special museum of industrial products, but only a few who use this facility to improve the performance of the industry. Though this facility helps in product introduction to visitors / tourists, especially study tour groups from schools and campuses. There has been no socialization of additional working capital programs through the People's Business Credit from the banking sector and is less likely to be touched by banks, except for traders who interact with banks in every business transaction.

There is support for the industry, although it does not help much to postproduction performance activities. The local government has provided a special museum of industrial products but only a few small who use this facility to improve the performance of the industry. The existence of museum products (displays) provided by the local government so far has been limited to product introduction to visitors / tourists, especially study tour groups from schools and campuses outside the pottery center. The People's Business Credit from the banking sector as an additional business capital has been offered, but there is no socialization from the Regional Government or Banking for the programs launched by the central government in the regions. This causes the small possibility for traders to access banking credit facilities, except for traders who interact with banking in every business transaction. From the marketing side, the current market share percentage is $20 \%$ of the local market and $80 \%$ of exports, with the largest local market being Jakarta. Traders have been actively participating in exhibitions aimed at increasing export sales. One of the exhibitions that was followed was the one organized by DIKTI (STSI) with the theme "Production, Marketing and Infrastructure Cooperation".

\section{Conclusion}

Based on the qualitative and quantitative approaches conducted in this study, internal and external factors have been described for the Pottery Center in Indonesia to implement a rebranding strategy. So it can be concluded that the formulation of the rebranding strategy of the Pottery Center in Indonesia is by conducting market 
penetration, market development, and product development. This strategy needs to be done to make the Pottery Center in Indonesia a tourist icon.

\section{Sugesstions}

The limitation of this research is the scope of exploration in the study area. The study was conducted at the Indonesian Pottery Center in Java alone. Even so, the Indonesian Pottery Center is a pottery center that has existed for a long time and is the biggest in Indonesia. The implication of this research is to increase the brand strength of the Indonesian Pottery Center, a rebranding strategy that involves all stakeholders is needed, by way of market penetration, market development, and product development.

\section{Aknowledgment}

Thanks to the Institut Ilmu Sosial dan Manajemen Stiami Jakarta, Indonesia for the funding that has been provided to carry out this research.

\section{References}

[1] Creswelsl, J. W. (2014) Research design: qualitative, quantitative, and mixed methods. Available at: http://pustakapelajar.co.id/buku/research-designpendekatan-kualitatif-kuantitatif-dan-mixed/.

[2] David, F. R. (2011) Strategic Management. Available at: http://36.67.167.42:8123/inlislite3/opac/detail-opac?id=25593.

[3] Lambkin, M. C. and Muzellec, L. (2010) 'Leveraging brand equity in businessto-business mergers and acquisitions', Industrial Marketing Management, 39(8), pp. 1234-1239. doi: 10.1016/j.indmarman.2010.02.020.

[4] Ločmele, G. and Mousten, B. (2016) 'A Tale of Two Re-branded Cities: Riga, Latvia and Aarhus, Denmark', Procedia - Social and Behavioral Sciences, 231, pp. 208-215. doi: 10.1016/j.sbspro.2016.09.093.

[5] Muzellec, L. M. D. M. L. (2003) 'Corporate Rebranding: An Exploratory Review.' Available at: http://www.academia.edu/1461036/Corporate_rebrandingan_exploratory_review.

[6] Prayudi; Juanita (2005) 'Strategic Corporate Communication dalam Proses Repositioning dan Rebranding’. doi: https://doi.org/10.24002/jik.v2i2.248.

[7] Samuel, M. (2015) 'Identities-in-transit--the--re-connections-and--rebrand_2015_Journal-of-His’. doi: https://doi.org/10.1016/j.jhg.2015.07.002.

[8] Sedarmayanti (2014) Manajemen Strategi. Bandung: PT. Refika Aditama. Available

https://openlibrary.telkomuniversity.ac.id/pustaka/98839/manajemenstrategi.html.

[9] Tjiptono, F. (2005) Brand Strategy and Management. Available at: https://scholar.google.co.id/scholar?hl=en\&as_sdt=0,5\&cluster=1727880603277 5140103.

[10] https://www.tempolagu.com > Seni Budaya > Seni Rupa is accessed on June, 28 2018

[11] https://lipsus.kontan.co.id/v2/gerabah/read/340/Sejarah-dan-PerkembanganSentra-Gerabah-Plered is accessed on June, 302018 
